\title{
Monikasvoinen tutkimusetiikka ja kohtaavat traditiot - nuoret folkloristit Riiassa
}

\author{
Reflecting on Disciplinary Ethics in Folkloristics: $8^{\text {th }}$ International Conference \\ of Young Folklorists. 19.-21. syyskuuta 2018, Riika, Latvia
}

\section{Tuukka Karlsson ja Viliina Silvonen}

\footnotetext{
T atvian Riiassa järjestettiin syyskuun lopulla nuorten folkloristien konferenssi jo kahdek-

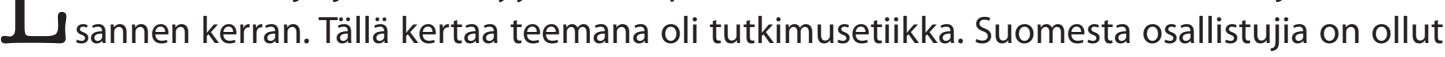
vuosien varrella vaihtelevasti: Riiassa mukana olivat vain allekirjoittaneet. Balttialaisvoimin organisoituja Young Folklorists -konferensseja on järjestetty vuosittain 2011 alkaen, ja aktiivisena taustavoimana on toiminut Tarton folkloristiikan professori Ülo Valk.
}

Esitelmien aiheiden kirjo oli laaja, ja tutkimuseettisiä kysymyksiä lähestyttiin niin kenttätöiden kuin arkistoaineiston näkökulmista. Esitelmissä sivuttiin muun muassa tutkijan vastuuta, informantin oikeuksia, fallibilismia, autenttisuutta (ja käsitteen ongelmallisuutta), unohtamatta tutkimusetiikkaan nivoutuvia poliittisia aspekteja.

\section{Intialaisten vähemmistöjen perinnettä ja venäläistä strukturalismia}

Leijonanosa Riikaan kolmeksi päiväksi kokoontuneista osallistujista oli saapunut Baltian maista, erityisesti Tarton yliopistosta. Kauimpaa matkustaneet olivat lentäneet paikalle Intiasta. Esitelmiä olikin runsaasti intialaisesta folkloresta, niin Tarton kansainvälisten ohjelmien opiskelijoilta kuin Intiasta saakka saapuneilta folkloristeilta. Kaikkiaan esitysten taso oli vaihteleva, mihin vaikuttivat esiintyjien vaihe tutkijanuralla - mukana oli useampikin maisterivaiheen opiskelija - valittu aihe sekä traditio, jonka piiristä puhuja tuli.

Tutkimusparadigmalliset erot olivat erityisen näkyviä juuri intialaisten konferenssipapereissa, joista suurin osa esitteli väitöskirjatutkijan oman kotialueen ja vähemmistöryhmän traditiota. Tällaisissa esitelmissä näkyi vahvana katoavan perinteen eetos: esitelmien pitäjien tiedonintressi tuntui suuntautuvan vahvasti ilmiöiden tallettamiseen ja esittämiseen, usein emansipatorisessa hengessä.

Tällainen suuntautuminen voidaan ymmärtää, kun otetaan huomioon Intian valtava kielellinen ja etninen diversiteetti: viimeisimmän laskennan mukaan Intiassa puhutaan 19569 eri 
kieltä äidinkielenä (Census of India 2011, 6). Ei siis ihme, että tutkija voi tuntea tarvetta oman etnisen vähemmistön aseman parantamiseen tuomalla sitä yleisempään tietoisuuteen.

Kyseisten esitelmien ongelmaksi nousi kuitenkin lähes täydellinen analyyttisyyden ja reflektion puute. Paperien sisältö koostui etnografisesta kuvailusta, mutta tutkijan asemointia tai metodologisia valintoja ei juurikaan tuotu esille. Ottaen huomioon konferenssin aiheen, pohdinta objektiivisuuden vaihtelevista merkityksistä tai esimerkiksi omassa yhteisössä tehdyn kenttätyön etiikasta olisi ollut tervetullutta.

Intialaisesitelmien lisäksi hämmästelyä herätti Moskovan koulukunnan folkloristiikan piirin esitelmä, josta kävi ilmi, että heillä folkloristiikka keskittyy yhä pitkälti rakenteiden ja toistuvuuksien tarkasteluun - teksteihin ilman konteksteihin kohdistuvaa huomiota. Strukturalismi näyttää siis olevan vahva ja ilmeisesti ainoa kannustettu tutkimussuuntaus sikäläisessä folkloristiikassa.

Esitelmästä nousi esiin huoli puhujan omasta positiosta tutkimuskentällä, sillä hänen kiinnostuksensa ei ollut niinkään kertomusten ja tekstien rakenteissa vaan kerrotussa sisällössä ja merkityksissä. Hän koki paikkansa strukturalismia vaalivan tutkimustradition piirissä ulkopuoliseksi ja pohtikin, pitäisikö hänen alkaa nimittää itseään antropologiksi, kuten hänen ohjaajansa olivat hänelle vihjanneet. Tällaiselle vastakkainasettelulle ei nykytutkimuksen piirissä kuitenkaan ole tarvetta - siitä konferenssiväki oli samaa mieltä.

Toinen esitelmässä esiin noussut hämmentävä seikka oli tutkimusetiikan keskeiskysymys. Puhuja kertoi vilpittömästi, että ei nähnyt ongelmaa jättää haastateltavan toive täyttämättä ja sammuttaa nauhuria, vaikka tutkimushaastateltava sitä pyysi. Kyseinen lähestymistapa herätti luonnollisesti inmetystä ja pään pyörittelyä yleisössä - tutkimusetiikkaa ei pitäisi lähestyä poimimalla rusinoita pullasta, saati pelkkänä akateemisena pyörittelynä, jossa eettiset suuntaviivat katoavat kentälle lähtiessä. Tutkijan ei tule olla erehtymätön, mutta vaarallisilla vesillä liikutaan, mikäli itsereflektio puuttuu kokonaan.

\section{Keynote-luennot: perinne, kulttuuriperintö ja omistajuus}

Keynote-luennot osuivat konferenssin aiheen ja muun ohjelman ytimeen. Toisen konferenssipäivän aloitti professori Valdimar Tr. Hafstein Islannin yliopistosta käsitellen perinteen tekijänoikeuksia. Luennolla purettiin islantilaisen kansanlaulun tapausta. Teeman parissa jatkettiin leffaillassa, jossa nähtiin myös Hafsteinin debyytti elokuva-alalla: The Flight of the Condor: A Letter, a Song, and the Story of Intangible Cultural Heritage (2018). Dokumentissa tekijänoikeuskeskusteluja vuosikymmenet aitiopaikoilta seurannut ja aktiivisesti keskusteluun osallistunut Hafstein kertoi El Condor Pasa -sävelmän kierrosta ympäri maailmaa. Aineettoman kulttuuriperinnön ja tekijänoikeuksien sekä kulttuurisen omistamisen ja tradition merkitysten suhteita perkaava puolituntinen on tulossa vapaasti katsottavaksi Vimeo-palveluun.

Perjantai-aamun keynote-luennoitsija oli samaa asiantuntijuuden raskasta sarjaa: Latvian kulttuuriakatemian dosentti Anita Vaivade toimii muun muassa UNESCOn aineetonta kulttuuriperintöä ja sitä koskevaa lainsäädäntöä käsittelevässä jaostossa johtotehtävissä. Hän lähestyi tutkimusetiikkaa erityisesti suostumuksen hankkimisen ja tutkijan velvollisuuksien käsitteiden kautta. UNESCOn aineetonta kulttuuriperintöä koskevaan yleissopimukseen 
pohjaten Vaivade käsitteli sekä tutkijan kohtaamia haasteita että lainsäädännöllisiä näkökohtia.

Konferenssin jälkimainingeissa täytyy todeta, että koemme olevamme kovin etuoikeutettuja voidessamme olla suomalaisia folkloristeja. Pitkän historiamme ja ainutkertaisten arkistoitujen materiaaliemme lisäksi meillä on laadukasta ja kriittistä opetusta ja mahdollisuus tutustua monipuoliseen, kansainväliseen teoreettiseen kenttään kielitaitomme ansiosta.

Ensi vuonna YoFo-konferenssi järjestetään Vilnassa. Vuoden 2020 konferenssia kaavaillaan Helsinkiin!

\section{Lähteet}

Census of India 2011. http://censusindia.gov.in/2011Census/C-16 25062018 NEW.pdf.

FM Tuukka Karlsson ja FM Viliina Silvonen ovat folkloristiikan väitöskirjatutkijoita Helsingin yliopistossa. 